\title{
Significance of Silica Fume on the Mechanical Properties of Recycled Aggregate Concrete
}

\author{
J. Kalyana Chandrasekhar Reddy ${ }^{1}$, P. S. S. Anjaneya Babu ${ }^{2}$ \\ ${ }^{1}$ PG Student, Department of Civil Engineering, Gudlavalleru Engineering College, Andhra Pradesh, India \\ ${ }^{2}$ Assistant Professor, Department of Civil Engineering, Gudlavalleru Engineering College, Andhra Pradesh, India
}

\begin{abstract}
The various studies related to sustainable concrete construction have encouraged recycled aggregate which is a partial replacement of natural aggregate in concrete mixes. The significance of silica fume (SF) in concrete mix will improve the quality of recycled aggregates in concrete. The Portland cement was replaced with Silica Fume at 0\%, 5\% and 10\%. The coarse aggregate in concrete mix is replaced by 0\%, 25\%, 50\%, 75\%, and 100\% of recycled coarse aggregates (RCA). The compressive strength and split tensile strength of concrete made with recycled aggregates are evaluated. Manufacturing of recycled aggregate concrete with silica fume consists of different methods to increase the strength of RCA such as surface treatments, three stage mixing and pozzolanic material. In this paper, the method of using pozzolanic material is studied. In this silica fume is used as pozzolanic material. In this study, the mixing of concrete is done by triple mix method. With silica fume as an admixture recycled aggregate concrete of M35 grade will be manufactured and tested for physical and mechanical properties. These strength results obtained is compared with conventional concrete results. The target strength is achieved at $5 \%$ replacement of silica fume.
\end{abstract}

Keywords: Recycled aggregate, Recycled coarse aggregate concrete, Silica fume, Compressive strength, Split tensile strength.

\section{Introduction}

Concrete is considered as the basic material for every type of construction and is mostly used. With the increase in the population and the fast development in industrialization and infrastructures causes huge construction activities. Very large quantities of demolished concrete waste materials are increased due to the collapsing of reinforced concrete buildings. The solid waste generated due to the demolition of construction activities is more. Generally recycled aggregates contains high absorption, rough texture and angular than natural aggregates. So, to increase the strength of recycled aggregates, pozzolanic materials are used. In this study silica fume is used as pozzolanic material.

Researchers like N.Siva kumar et al., (2014)[1] studied the effect of micro silica and the strength of concrete with ordinary Portland cement. N.K.Amudhavalli et al., (2012)[2] studied the influence of silica fume on concrete. Ozgur Cakir et al., (2014)[3] studied the influence of silica fume on mechanical and chemical properties of recycled aggregate concrete. I.R. Isan Raj at al., (2015)[4] studied on the effect of silica fume on the properties of recycled aggregate concrete. Kalaiarasu et al., (2006)[5] have studied on the properties of high performance concrete with micro silica and in combination with recycled coarse aggregate.

In this study the various percentages of recycled aggregate were added to coarse aggregates and $5 \%$ and $10 \%$ of silica fume is replaced with cement. The compressive strength and split tensile strength are observed.

\section{Materials}

The usage of natural aggregate is getting more and more intense with the advanced development in infrastructure area. In order to reduce the usage of natural aggregate, recycled aggregate can be used as the replacement materials. These recycled coarse aggregates are obtained by crushing and chipping of the cubes that are casted with M35 grade mix design.

\subsection{Recycled Coarse Aggregates (RCA):}

Recycled coarse aggregates are comprised of crushed, graded inorganic particles processed from the materials that have been used in the constructions and demolition debris. Recycled concrete aggregates mainly differ from natural aggregates in that they are composed of two different materials:

1) Natural aggregate and

2) Cement mortar attached.

Recycled coarse aggregate are obtained from concrete waste. Recycled aggregates contains high absorption, rough texture and angular than natural aggregates that affect the concrete mix proportion. The environmental benefits increase by using these recycled coarse aggregates in the preparation of new concrete. Hence, recycling of the concrete waste can be considered as an excellent source of coarse aggregate for the production of new concrete.

The recycled coarse aggregates are highly heterogeneous and have high porosity and also have high impurity content. The characteristics of recycled aggregates are influenced by heterogeneity and the compressive strength, tensile strength reduces due to the increase of porosity in concrete and have a weak aggregate- matrix interfacial bonding. To increase the properties of recycled aggregate concrete there are methods such as surface treatments, mixing methods and pozzolanic materials. In surface treatment, collected recycled coarse aggregate is cleaned with different acids to increase the strength of recycled coarse aggregate. There are three methods of mixing. They are normal mixing method (NM), double mixing method (DM) and triple mixing method (TM)[8] as shown in fig.1. Pozzolanic materials 


\section{International Journal of Science and Research (IJSR) \\ ISSN (Online): 2319-7064 \\ Index Copernicus Value (2013): 6.14 | Impact Factor (2015): 6.391}

improves the strength of recycled coarse aggregate by filling air voids which were occurred in recycled coarse aggregate and also by using pozzolanic material it increases the bond strength between motor and cement paste.

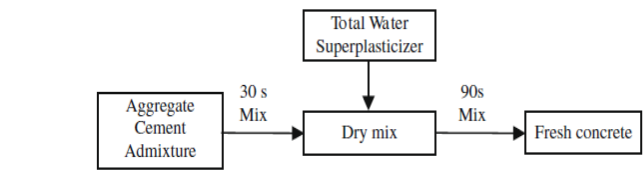

(a) Normal mixing method (NM)

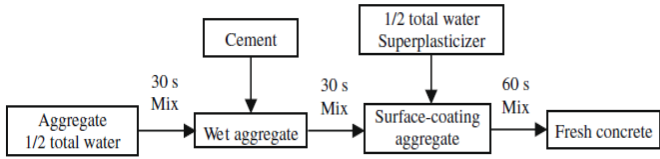

(b) Double mixing method (DM), coating with cement and admixture

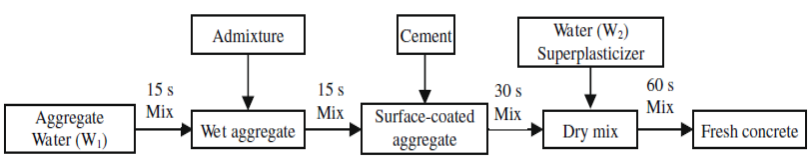

(c) Triple mixing method (TM), coating with admixture

Figure 1: Types of mixing methods

In this study, the pozzolanic material is used to improve the strength of the recycled aggregate concrete. Silica Fume or micro silica is used as the pozzolanic material. The details of replacement of recycled coarse aggregates in natural coarse aggregates are shown in Table 1.

Table 1: The details of replacement of recycled coarse aggregates in natural coarse aggregates

\begin{tabular}{|c|c|c|c|c|c|}
\hline & \multicolumn{5}{|c|}{ Mix $(0.43 \mathrm{~W} / \mathrm{C}$ ratio $)$} \\
\hline NCA & $100 \%$ & $75 \%$ & $50 \%$ & $25 \%$ & $0 \%$ \\
\hline RCA & $0 \%$ & $25 \%$ & $50 \%$ & $75 \%$ & $100 \%$ \\
\hline
\end{tabular}

For this study, two different types of coarse aggregates were used in the preparation of concrete i.e. Natural coarse aggregate (NCA) and Recycled coarse aggregate (RCA). Both NCA and RCA aggregates were screened into two different size fractions (i.e. $70 \%$ of $20 \mathrm{~mm}$ to $16 \mathrm{~mm}$ sized and $30 \%$ of $12 \mathrm{~mm}$ to $10 \mathrm{~mm}$ sized) and combined to form NCA \& RCA.

\subsection{Silica Fume}

Silica fume, also known as micro silica, is a by-product material that is used as a pozzolan. This by-product is a result of the reduction of high-purity quartz with coal in an electric arc furnace in the manufacture of silicon or ferrosilicon alloy. Silica fume rises as an oxidized vapour from the $2000^{\circ} \mathrm{C}$ furnaces. When it cools it condenses and is collected in huge cloth bags. The condensed silica fume is then processed to remove impurities and to control particle size. Condensed silica fume is essentially silicon dioxide (usually more than $85 \%$ ) in noncrystalline form. Since it is an airborne material like fly ash, it has a spherical shape. Since it is an extremely with fine particles, the diameter is 1 $\mu \mathrm{m}$ with an average diameter of $0.1 \mu \mathrm{m}$. This is 100 times smaller than cement particles.

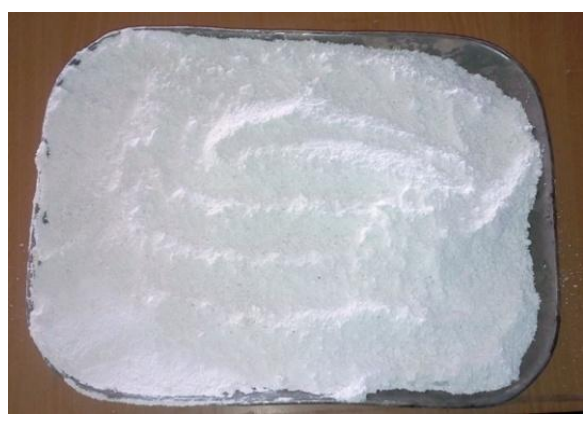

Figure 2: silica fume

The Silica fume is used as a partial replacement of cement. The chemical composition and physical properties of silica fume are as follows:

Table 2: The chemical composition of silica fume

\begin{tabular}{|c|c|}
\hline Components & Silica fume \\
\hline Silica $\left(\mathrm{SIO}_{2}\right)$ & $99.886 \%$ \\
\hline Alumina $\left(\mathrm{AI}_{2} \mathrm{O}_{3}\right)$ & $0.043 \%$ \\
\hline Ferric Oxide $\left(\mathrm{Fe}_{2} \mathrm{O}_{3}\right)$ & $0.040 \%$ \\
\hline Titanium Oxide $\left(\mathrm{TiO}_{2}\right)$ & $0.001 \%$ \\
\hline Calcium Oxide $(\mathrm{CaO})$ & $0.001 \%$ \\
\hline Magnesium Oxide $(\mathrm{MgO})$ & $0.000 \%$ \\
\hline Pottasium Oxide $\left(\mathrm{K}_{2} \mathrm{O}\right)$ & $0.001 \%$ \\
\hline Sodium Oxide $\left(\mathrm{Na}_{2} \mathrm{O}\right)$ & $0.003 \%$ \\
\hline Loss On Ignition & $0.015 \%$ \\
\hline
\end{tabular}

Table 3: The physical properties of silica fume

\begin{tabular}{|c|c|}
\hline Physical Properties & Results \\
\hline Physical State & Micronized powder \\
\hline Odour & Odorless \\
\hline Appearance & White colour powder \\
\hline Colour & White \\
\hline Pack Density & $0.76 \mathrm{gm} / \mathrm{cc}$ \\
\hline $\mathrm{pH}$ of 5\% Solution & 6.90 \\
\hline Specific Gravity & 2.63 \\
\hline Moisture & $0.058 \%$ \\
\hline Oil Absorption & $55 \mathrm{ml} / 100 \mathrm{gms}$ \\
\hline
\end{tabular}

\section{Mix Design}

Concrete mix proportions were designed as per IS 10262:2009 code. A super plasticizer of SP430 was used for high degree of workability. The content of super plasticizer was $0.9 \%$ of cement used. The resulting concrete is proportioned for M35 grade as per nominal mix design. The natural coarse aggregate is replaced by recycled coarse aggregate in percentages i.e., $0 \%, 25 \%, 50 \%, 100 \%$ and these specimens were tested for compression and split tensile strengths. The variations of compressive strength and split tensile strength with fly ash and without fly ash are discussed in the result section.

\subsection{Mix Proportions}

Here three mixes of concrete were prepared i.e., without replacement of silica fume, with the replacement of silica fume by $5 \%$ and $10 \%$ respectively. The water-cement ratio is 0.43. And when super plasticizer (SP430) is used the water-cement ratio is 0.42 . The crushed aggregates are used for the replacement of natural aggregates in different

\section{Volume 5 Issue 6, June 2016 www.ijsr.net}




\section{International Journal of Science and Research (IJSR) \\ ISSN (Online): 2319-7064 \\ Index Copernicus Value (2013): 6.14 | Impact Factor (2015): 6.391}

proportions such as $0 \%, 25 \%, 50 \%, 75 \%$, and $100 \%$. The tables 3 show the mix proportions of recycled aggregate concrete without silica fume. Tables 4 and 5 shows the mix proportions of recycled aggregate concrete with $5 \%$ and $10 \%$ silica fume.

Table 3: Without replacement of silica fume

\begin{tabular}{|c|c|c|c|c|c|c|c|}
\hline \multirow{2}{*}{ RAC Mix } & \multirow{2}{*}{$\begin{array}{c}\text { Source of RCA } \\
\text { (Parent concrete) }\end{array}$} & \multirow{2}{*}{$\begin{array}{c}\% \\
\text { RCA }\end{array}$} & \multicolumn{6}{|c|}{ Mix proportions $\left(\mathrm{Kg} / \mathrm{m}^{3}\right)$} \\
\cline { 3 - 9 } & & 25 & 385.185 & 808.157 & 888.043 & 296.01 & 171.852 \\
\hline \multirow{3}{*}{ M35 } & \multirow{3}{*}{ M35 (RAC 35) } & 50 & 385.185 & 808.157 & 592.029 & 592.029 & 171.852 \\
\cline { 3 - 9 } & & 75 & 385.185 & 808.157 & 296.01 & 888.043 & 171.852 \\
\cline { 3 - 9 } & & 100 & 385.185 & 808.157 & 0 & 1184.05 & 171.852 \\
\hline
\end{tabular}

Table 4: With 5\% replacement of silica fume

\begin{tabular}{|c|c|c|c|c|c|c|c|c|}
\hline \multirow{2}{*}{$\begin{array}{l}\text { RAC } \\
\text { Mix }\end{array}$} & \multirow{2}{*}{$\begin{array}{c}\text { Source of RCA } \\
\text { (Parent concrete) }\end{array}$} & \multirow{2}{*}{$\begin{array}{c}\% \\
\text { RCA }\end{array}$} & \multicolumn{6}{|c|}{ Mix proportions $(\mathrm{Kg} / \mathrm{m} 3)$} \\
\hline & & & Cement & Silica fume $(10 \%)$ & FA (Sand) & NCA & RCA & Water \\
\hline \multirow{4}{*}{ M35 } & \multirow{4}{*}{$\begin{array}{c}\text { M35 } \\
\text { (RAC 35) }\end{array}$} & 25 & 346.67 & 38.52 & 808.157 & 888.04 & 296.01 & 167.86 \\
\hline & & 50 & 346.67 & 38.52 & 808.157 & 592.03 & 592.03 & 167.86 \\
\hline & & 75 & 346.67 & 38.52 & 808.157 & 296.01 & 888.04 & 167.86 \\
\hline & & 100 & 346.67 & 38.52 & 808.157 & 0 & 1184.058 & 167.86 \\
\hline
\end{tabular}

Table 5: With $10 \%$ replacement of silica fume

\begin{tabular}{|c|c|c|c|c|c|c|c|c|}
\hline \multirow{2}{*}{$\begin{array}{l}\text { RAC } \\
\text { Mix }\end{array}$} & \multirow{2}{*}{$\begin{array}{c}\text { Source of RCA } \\
\text { (Parent concrete) }\end{array}$} & \multirow{2}{*}{$\begin{array}{c}\% \\
\text { RCA }\end{array}$} & \multicolumn{6}{|c|}{ Mix proportions $(\mathrm{Kg} / \mathrm{m} 3)$} \\
\hline & & & Cement & Silica fume $(5 \%)$ & FA (Sand) & NCA & $\mathrm{RCA}$ & Water \\
\hline \multirow{4}{*}{ M35 } & \multirow[t]{4}{*}{ M35 (RAC 35) } & 25 & 365.93 & 19.26 & 808.157 & 888.04 & 296.01 & 167.86 \\
\hline & & 50 & 365.93 & 19.26 & 808.157 & 592.03 & 592.03 & 167.86 \\
\hline & & 75 & 365.93 & 19.26 & 808.157 & 296.01 & 888.04 & 167.86 \\
\hline & & 100 & 365.93 & 19.26 & 808.157 & 0 & 1184.058 & 167.86 \\
\hline
\end{tabular}

\section{Results and Discussions}

\subsection{Compressive Strength}

The experimental results obtained after the curing of 7 days and 28 days are shown in the table 6. The compressive strength of the two sets is decreased with the increase in percentage of recycled aggregates. At 28 days $100 \%$ replacement of RCA with addition of silica fume achieves strength of $32.63 \mathrm{MPa}$. In a long period of time this strength can the equal or exceed to the strength of natural aggregate concrete.

Table 6: Compressive strength for 7 and 28 days with and without silica fume

\begin{tabular}{|c|c|c|c|c|c|c|}
\hline \multirow{2}{*}{$\begin{array}{c}\text { \% of } \\
\text { RA }\end{array}$} & \multicolumn{5}{|c|}{ Compressive strength (MPa) } \\
\cline { 2 - 7 } & Without S.F & With S.F (5 \%) & With S.F (10 \%) \\
\hline 0 & 30.68 & 28 days & 7 days & 28 days & 7 days & 28 days \\
\hline 25 & 29.76 & 44.68 & 31.54 & 46.78 & 29.47 & 44.54 \\
\hline 50 & 28.37 & 43.66 & 29.12 & 45.69 & 27.54 & 42.37 \\
\hline 75 & 25.02 & 39.91 & 27.32 & 41.53 & 26.61 & 40.28 \\
\hline 100 & 23.87 & 35.84 & 25.63 & 38.59 & 21.26 & 35.56 \\
\hline
\end{tabular}

\subsection{Split Tensile Strength}

The split tensile strength results obtained after 7 days and 28 days of curing are shown in table 7 . The split tensile strength of the two sets is also decreased with increase in the percentage of recycled aggregates.
Table 7: Split tensile strength for 7 and 28 days with and without silica fume

\begin{tabular}{|c|c|c|c|c|c|c|}
\hline \multirow{2}{*}{$\begin{array}{c}\text { \% of } \\
\text { RA }\end{array}$} & \multicolumn{6}{|c|}{ Split tensile strength (MPa) } \\
\cline { 2 - 7 } & \multicolumn{2}{|c|}{ Without S.F } & \multicolumn{2}{|c|}{ With S.F (5 \%) } & \multicolumn{2}{|c|}{ With S.F (10\%) } \\
\cline { 2 - 7 } & 7 days & 28 days & 7 days & 28 days & 7days & 28 days \\
\hline 0 & 3.77 & 4.82 & 3.64 & 4.58 & 3.39 & 4.33 \\
\hline 25 & 3.41 & 4.65 & 3.27 & 4.29 & 3.20 & 4.07 \\
\hline 50 & 3.21 & 4.42 & 2.97 & 3.91 & 3.07 & 3.71 \\
\hline 75 & 2.93 & 4.01 & 2.76 & 3.72 & 2.87 & 3.45 \\
\hline 100 & 2.73 & 3.67 & 2.57 & 3.51 & 2.64 & 3.26 \\
\hline
\end{tabular}

Figure 3 and figure 4 shows the variation of compressive strength for 7 days and 28 days. And figure 5 and figure 6 shows the variation of split tensile strength for 7 days and 28 days.

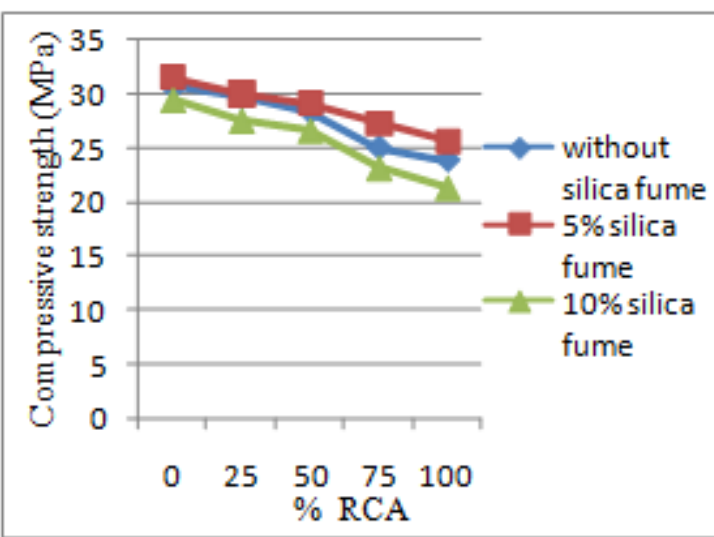

Figure 3: Compressive strength for 7 days without silica fume and $5 \%, 10 \%$ silica fume

\section{Volume 5 Issue 6, June 2016 www.ijsr.net}




\section{International Journal of Science and Research (IJSR) \\ ISSN (Online): 2319-7064}

Index Copernicus Value (2013): 6.14 | Impact Factor (2015): 6.391

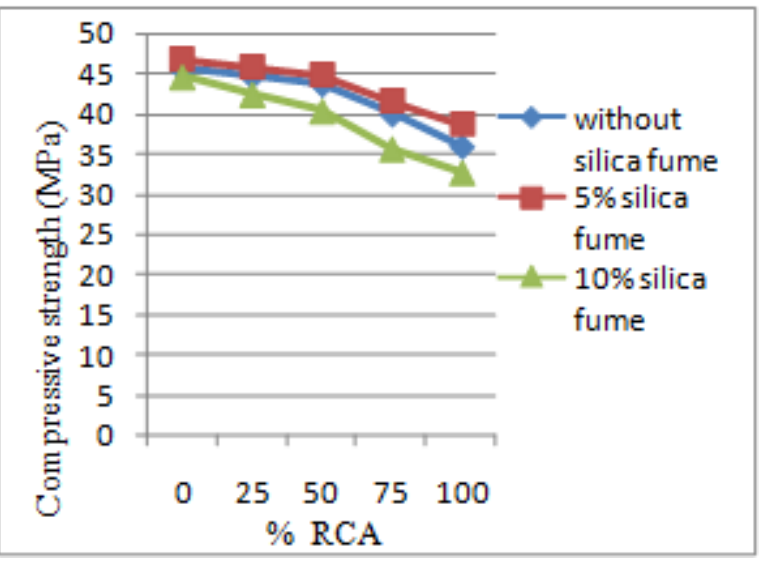

Figure 4: Compressive strength for 28 days without silica fume and $5 \%, 10 \%$ silica fume

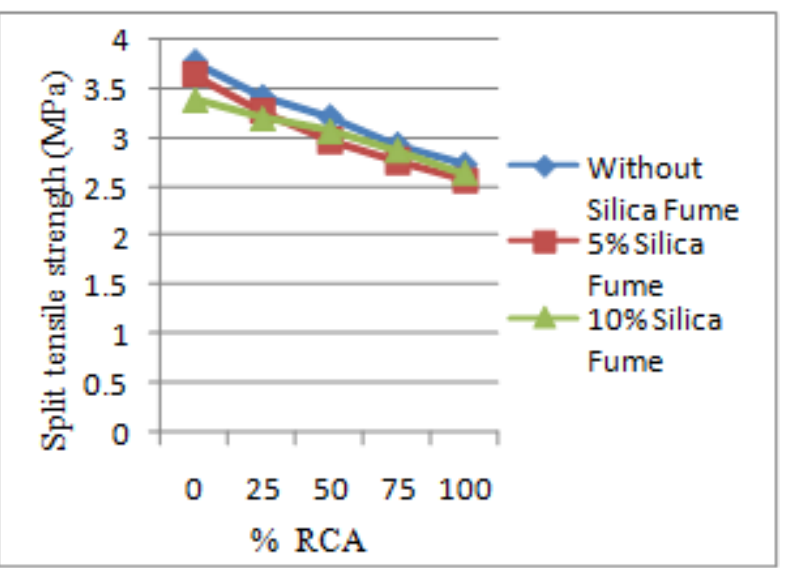

Figure 5: Split tensile strength at 7 days without silica fume and $5 \%, 10 \%$ silica fume

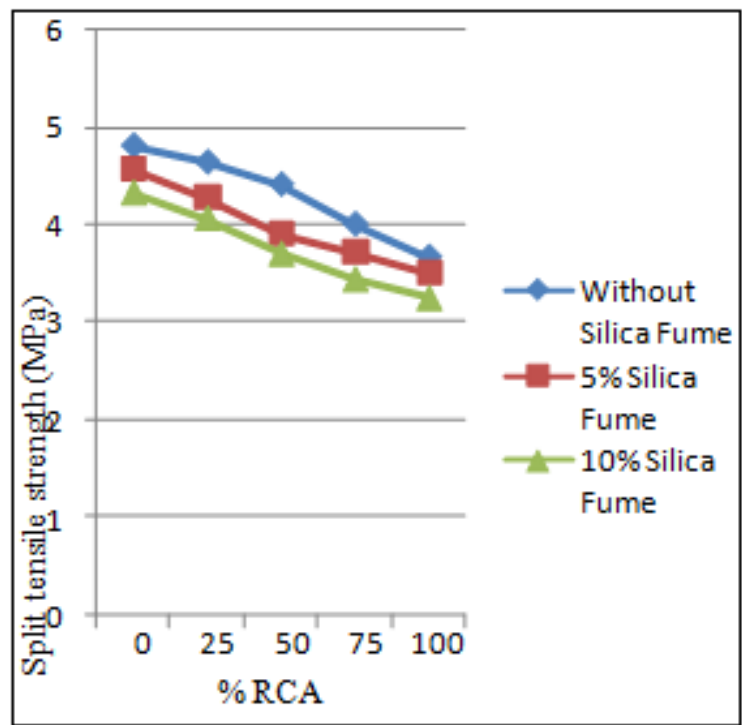

Figure 6: Split tensile strength at 28 days without silica fume and 5\%, $10 \%$ silica

\section{Conclusion}

From the study following conclusion are made:

1) The reduction in compressive strength of recycled concrete is observed when the natural aggregates are replaced with recycled coarse aggregate by 25, 50, 75 and $100 \%$ respectively. This may be because of the loose mortar around the recycle aggregate which do not allow the proper bonding between the cement paste and aggregate.

2) For $10 \%$ replacement of silica fume in cement the strength value decreases when compared to $5 \%$ of silica fume.

3) At 28 days $100 \%$ replacement of RCA with addition of silica fume achieves strength of $32.63 \mathrm{MPa}$. In a long period of time this strength can the equal or exceed to the strength of natural aggregate concrete.

4) The split tensile strength is less for pozzolanic materials and increases with long period of time

\section{References}

[1] N. Sivakumar, S. Muthukumar, Experimental Studies on High Strength Concrete by using Recycled Coarse Aggregate, International Journal of Engineering And Science Vol.4, Issue 01 (January 2014), PP 27-36.

[2] N. K. Amudhavalli, P. Jeena Mathew(2006) " Effect of silica fume on strength and durability parameters of concrete", International Journal of Civil Engineering and Technology, Volume 3, Issue 2, 2012, pp. 322 332.

[3] Ozgur Cakir and Omer Ozkan Sofyanli.,(2014) studied the "Influence of silica fume on mechanical and chemical properties of recycled aggregate concrete", HBRC Journal (2015) 11, 157-166.

[4] Hansen, T. C., "An Experimental Investigation on strength properties of concrete containing micro-silica and nano- silica". International Journal of Civil engineering and technology, volume 5, August (2014), pp. 89-97.

[5] M. Kalaiarasu, K. Subramanian (2006) "Properties of recycled aggregate concrete with silica fume", journal of applied science 6 (14): 2956-2958.

[6] Faiz A. M. Mirza and and Mohammed A. Saif (2010) "Mechanical properties of Recycled Aggregate concrete incorporating Silica Fume",second international conference on sustainable construction materials and technology,June 28,2010.

[7] Y. V. Akbari, N. K. Arora, M. D. Vakil, "Effect on recycled aggregate on concrete properties", International Journal of Earth Sciences and Engineering ISSN 0974-5904, Volume 04, No 06 SPL, October 2011, pp. 924-928.

[8] Deyu Kong, Ting Lei, Jianjun Zheng, Chengchang Ma, Jun Jiang, Jing Jiang, "Effect and mechanism of surface-coating pozzalanics materials around aggregate on properties and ITZ microstructure of recycled aggregate concrete", Construction and Building Materials 24 (2010) 701-708.

\section{Volume 5 Issue 6, June 2016 www.ijsr.net}

